\title{
The Effect of Monoterpenes on Swarming Differentiation and Haemolysin Activity in Proteus mirabilis
}

\section{Sergio Echeverrigaray ${ }^{1, *}$, Lessandra Michelim ${ }^{1,2}$, Ana Paula Longaray Delamare ${ }^{1}$, Cristiane Paim Andrade ${ }^{1}$, Sérgio Olavo Pinto da Costa ${ }^{1}$ and Jucimar Zacaria ${ }^{1}$}

1 Research Laboratory of Microbiology, Institute of Biotechnology, University of Caxias do Sul, Rua Francisco Getúlio Vargas, 1130, Caxias do Sul, Brazil 95070-560

2 Division of Infectious Diseases. General Hospital of Caxias do Sul, University of Caxias do Sul, Av. Prof Antonio Vignolli, 255, Caxias do Sul, Brazi195070-560; Email: lessandra@gmail.com (L. M.)

* Author to whom correspondence should be addressed; E-mail: selaguna@ucs.br; Tel.: +55 54 32182149; Fax: +55 5432182149 .

Received: 3 November 2008; in revised form: 19 November 2008 / Accepted: 27 November 2008 / Published: 15 December 2008

\begin{abstract}
Urinary tract infection by Proteus mirabilis depends on several virulence properties that are coordinately regulated with swarming differentiation. Here we report the antibacterial and anti-swarming effect of seventeen terpenoids, and the effect of subinhibitory concentrations of five selected terpenoids on swarming, biofilm formation and haemolysin activity. The results showed that all the terpenes evaluated, particularly oxygenated terpenoids, inhibited P. mirabilis with MIC values ranging between 3 and 10 $\mathrm{mg} / \mathrm{L}$. Moreover, citral, citronellol and geraniol effectively inhibit P. mirabilis swarming in a dose dependent manner, reducing swimming/swarming cell differentiation and haemolysin activity at 1/10 MIC concentration. The inhibition of $P$. mirabilis swarming and virulence factor expression by selected oxygenated terpenoids suggest that essential oils with high concentration of these compounds have the potential to be developed as products for preventing $P$. mirabilis infections.
\end{abstract}

Keywords: Terpenoids; Cell differentiation; Proteus mirabilis, MIC. 


\section{Introduction}

Proteus mirabilis is one of the most important pathogens associated with complicated urinary tract infections and bacteremia, affecting patients with anatomical abnormalities, immunodeficiency and long-term urinary catheterization $[1,2]$. Urinary tract infection with P. mirabilis start with bladder colonization, causing bacteriuria and cystitis, and can ascend to the kidneys, leading to acute pyelonephritis, chronic inflammation, kidney stones and renal failure.

A prominent feature of $P$. mirabilis is the ability to swarm on agar plates and form highly ordered and terraced colonies with characteristic concentric rings. Swarming is process in which short vegetative swimming cells differentiate to long highly flagellated forms referred to as swarmer cells $[1,3]$. Swarmer cell differentiation depends on surface contact, inhibition of flagellar rotation, cell density and cell-cell signaling $[4,5]$.

Several potential virulence factors including haemolysin, swarming, adhesins, proteases, and ureases, may be responsible for the pathogenicity of $P$. mirabilis [6-8]. The expression of virulence factors, including haemolysin, urease and protease, and the ability to invade human urothelial cells, is coordinately upregulated during swarming [5, 8-10]. Numerous compounds have been reported to prevent P. mirabilis swarming "in vitro". Among these are charcoal and barbitone [11], urea [12], ethanol and sodium azide [13], p-nitrophenylglycerol [12, 14, 15], fatty acids [16], and resveratrol [17].

Terpenes are secondary metabolites, represented by hemiterpenes, monoterpenes, sesquiterpenes and their terpenoid derivatives. These isoprenoid compounds are the main constituents of essential oils, being responsible for their aroma or flavor. Essential oils are obtained from spices, aromatic herbs, fruits, and flowers. Generally, the oil composition is a balance of various compounds, although in many species one constituent may prevail over all others [18].

Terpenes and terpenoids are active against bacteria, fungi, viruses, and protozoa [18]. The antibacterial action of terpenes is not fully understood but is speculated to involve membrane modifications resulting in alterations of membrane permeability and in leakage of intracellular materials [19]. Classified as Generally Recognized As Safe (GRAS), essential oils are used in food, cosmetics and pharmaceuticals, and have gained special interest because of the resistance to antibiotics that microorganisms have acquired [20,21].

In this study we evaluated the antimicrobial activity of several monoterpenes, and the effect of subinhibitory concentrations of these compounds on swarming, and haemolysin activity of Proteus mirabilis.

\section{Results and Discussion}

The anti-bacterial activity of seventeen monoterpenes against $P$. mirabilis L68, as revealed by their MIC values, is summarized in Table 1. The results showed that monoterpenes exhibited anti-bacterial activity with varying magnitudes. Citral, citronellol, geraniol, $\alpha$-terpineol, terpinene-4-ol, linalool, and pulegone were the most effective monoterpenes against $P$. mirabilis L68, with MIC values between 3 and $5 \mathrm{mg} / \mathrm{L}$. This results were confirmed with five other isolates of $P$. mirabilis and two isolates of $P$. vulgaris (data not show), indicating that these MIC values are representative of the antimicrobial activity of these monoterpenes against Proteus. 
Table 1. Minimum inhibitory concentration (MIC) and the effect of $1 / 10$ MIC concentration of monoterpenes on the swimming/swarming behavior of $P$. mirabilis L68.

\begin{tabular}{lcccc}
\hline Treatments & $\begin{array}{c}\text { MIC } \\
(\mathbf{m g} / \mathbf{L})\end{array}$ & $\begin{array}{c}\text { Colony } \\
\text { diameter } \\
(\mathbf{m m})^{\mathbf{1}^{\mathbf{1}}}\end{array}$ & $\begin{array}{c}\mathbf{N}^{\mathbf{o}} \text { of } \\
\text { concentic } \\
\text { rings }\end{array}$ & $\begin{array}{c}\text { Second ring } \\
\text { width (mm) }\end{array}$ \\
\hline pulegone & 5 & $53.2 \pm 1.5^{\mathrm{e}}$ & $5-6$ & $3.8 \pm 1.4^{\mathrm{bc}}$ \\
citronellol & 3 & $23.7 \pm 1.5^{\mathrm{f}}$ & $5-6$ & $1.0 \pm 0.5^{\mathrm{d}}$ \\
citronellal & 6 & $68.0 \pm 0.6^{\mathrm{b}}$ & 6 & $4.3 \pm 0.3^{\mathrm{b}}$ \\
citronellyl acetate & $>10$ & $79.2 \pm 3.5^{\mathrm{b}}$ & 6 & $4.5 \pm 0.9^{\mathrm{b}}$ \\
geraniol & 3 & $22.5 \pm 0.6^{\mathrm{f}}$ & $3-4$ & $0.8 \pm 0.3^{\mathrm{d}}$ \\
bornyl acetate & 10 & $71.3 \pm 1.5^{\mathrm{b}}$ & 6 & $4.3 \pm 0.3^{\mathrm{b}}$ \\
$\alpha$-terpinene & 7.5 & $79.3 \pm 3.5^{\mathrm{ab}}$ & $5-6$ & $6.1 \pm 2.2^{\mathrm{a}}$ \\
$\alpha$-terpineol & 5 & $49.6 \pm 1.0^{\mathrm{d}}$ & $4-5$ & $4.2 \pm 0.4^{\mathrm{b}}$ \\
terpinene-4-ol & 5 & $62.5 \pm 1.0^{\mathrm{c}}$ & $5-6$ & $4.5 \pm 1.3^{\mathrm{b}}$ \\
linalool & 6 & $72.8 \pm 1.7^{\mathrm{b}}$ & $5-6$ & $6.2 \pm 1.2^{\mathrm{a}}$ \\
linallyl acetate & $>10$ & $82.1 \pm 3.0^{\mathrm{a}}$ & 6 & $4.5 \pm 0.1^{\mathrm{b}}$ \\
limonene & 10 & $82.0 \pm 2.7^{\mathrm{a}}$ & 6 & $5.4 \pm 1.3^{\mathrm{ab}}$ \\
citral & 5 & $41.0 \pm 1.5^{\mathrm{d}}$ & $4-5$ & $2.8 \pm 1.0^{\mathrm{c}}$ \\
mentone & $>10$ & $66.7 \pm 1.7^{\mathrm{c}}$ & $5-6$ & $4.7 \pm 1.7^{\mathrm{b}}$ \\
$\beta$-pinene & $>10$ & $79.5 \pm 4.7^{\mathrm{ab}}$ & 6 & $7.0 \pm 3.6^{\mathrm{a}}$ \\
1,8-cineol & 7.5 & $74.6 \pm 2.5^{\mathrm{b}}$ & 6 & $3.0 \pm 0.9^{\mathrm{c}}$ \\
carveol & 10 & $83.2 \pm 1.7^{\mathrm{a}}$ & $5-6$ & $7.0 \pm 2.3^{\mathrm{a}}$ \\
Control & - & $84.2 \pm 3.5^{\mathrm{a}}$ & 6 & $6.5 \pm 2.2^{\mathrm{a}}$ \\
\hline${ }^{*}$ Colony diameter in LB swarming plates with $1 / 10 \mathrm{MIC}$ concentration $(0.3$ to 1 mg/L). Data were \\
obtained after 24h at $37^{\circ} \mathrm{C} ;{ }^{1}$ Means followed by the same letter are not significantly different \\
according to Tukey's test $(\mathrm{p}=0.05)$. & & & \\
\hline
\end{tabular}

MIC values obtained in the present work are in accordance with previous reports in which the antibacterial effect of essential oils extracted from several plants were determined [22]. Moreover, the seven most effective compounds against $P$. mirabilis, as determined by their MIC values, are oxygenated monoterpenes considered as broad spectrum antibacterial substances [23].

The effect of terpenes on Proteus (P. mirabilis, P. vulgaris and P. penneri) swarming behavior was indirectly reported by Mansouri et al. [24]. These authors showed that subinhibitory concentrations of the essential oils of Ferula gumosa, Lavandula officinalis, and Zataria multiflora modified or inhibited swarming.

To evaluate the effect of the monoterpenes on P. mirabilis swarming behavior, LB swarming agar plates containing 1/10 MIC concentration of each compound were seeded with a drop (5 $\mu \mathrm{L})$ of a stationary culture of wild-type L68 strain. These experiments showed that eight out of 17 compounds tested inhibited swarming significantly (Table 1). Swarming inhibition was evidenced by a reduction on colony diameter, the number of concentric rings, and ring width (Table 1 and Figure 1). The reduction of the number of concentric rings and ring width are first indicatives of the interference of sub-inhibitory concentrations of terpenoids on swimming/swarming cell differentiation and swarming cell motility. The eight compounds that effectively inhibit swarming were oxygenated monoterpenes. Four of them (citronellol, geraniol, $\alpha$-terpineol, and terpinene-4-ol) are oxygenated compounds with 
hydroxyl groups, one is a cyclized monoterpenes alcohol (1,8-cineol), and three are monoterpene esters (citronellal, citral and pulegone).

Figure 1. Swarming of Proteus mirabilis L68 on LB swarming agar plates without terpenes (a), and with $0.5 \mathrm{mg} / \mathrm{L}$ of $\alpha$-terpineol (b) and $0.3 \mathrm{mg} / \mathrm{mL}$ citronellol (c). Incubation period of $24 \mathrm{~h}$ at $37^{\circ} \mathrm{C}$.

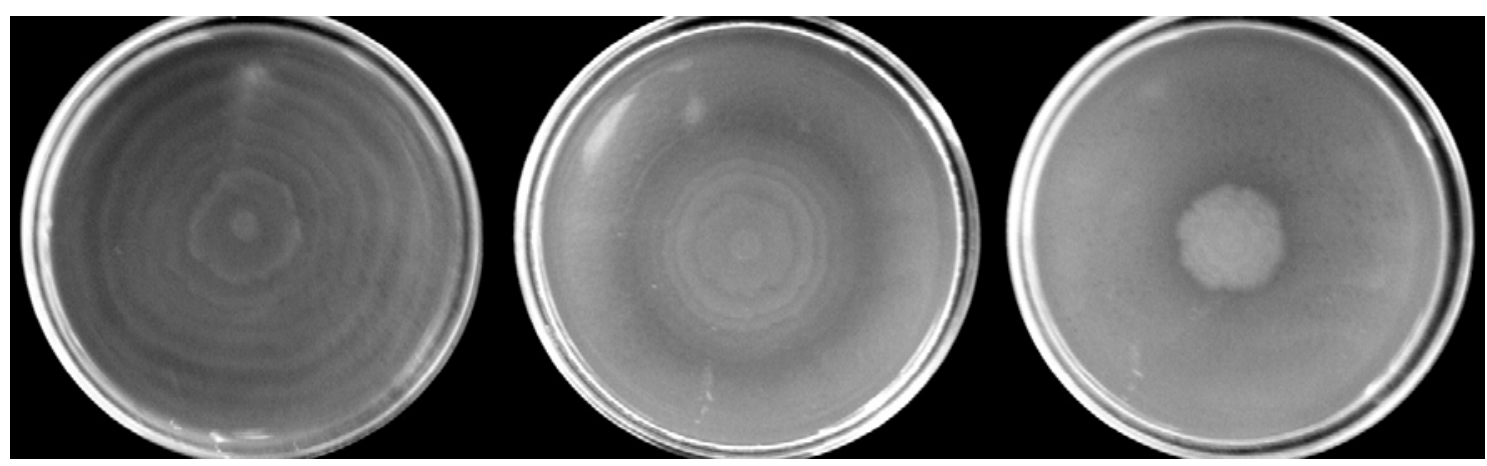

(a)

(b)

(c)

Comparison between the effect of citronellol, c1tronellal and citronellyl acetate, linalool and linallyl acetate, and geraniol and citral, indicate that hydroxyl group is important in the antibacterial activity and swarming inhibition of P. mirabilis by monoterpenes (Table 1). In general, the antimicrobial activity of a compound increases with the presence of an oxygen containing functional group, indicating a relationship between structure and biological activity [25, 26].

Figure 2. Chemical structures of monoterpenes with pronounced effect on swarming differentiation.<smiles>CC(C)=CCC/C(C)=C/C=O</smiles>

Citral<smiles>CC(C)=CCCC(C)=CCO</smiles>

Geraniol<smiles>CC(C)=CCCC(C)CCO</smiles>

Citronellol<smiles>CC(C)=C1CCC(C)CC1=O</smiles>

Pulegane<smiles>CC1=CCC(C(C)(C)O)CC1</smiles>

a-Terpineal

For further studies, we selected five terpenoids (citral, citronellol, $\alpha$-terpineol, geraniol, and pulegone, Figure 2) that exhibited significant reduction of $P$. mirabilis swarming. As can be observed in Figure 3, these terpenoids $(0.3$ to $0.5 \mathrm{mg} / \mathrm{L})$ reduce colony expansion over time. Moreover, swimming/swarming cyclic differentiation was not observed in the presence of citronellol and geraniol. To test whether swarming inhibition was dose dependent, the selected monoterpenes at 0.06 , 
$0.12,0.25,0.5$, and $0.75 \mathrm{mg} / \mathrm{L}$ were added to LB swarming agar plates, and colony diameter evaluated after $18 \mathrm{~h}$ at $37^{\circ} \mathrm{C}$.

Figure 3. Effect of selected monoterpenes on the swarming behavior of Proteus mirabilis (L68 wild strain): $\bigcirc$ control (no terpenes), $\bigcirc$ pulegone $(0.5 \mathrm{mg} / \mathrm{L}), \boldsymbol{\Delta} \operatorname{citral}(0.5 \mathrm{mg} / \mathrm{L}), \triangle$ geraniol $(0.3 \mathrm{mg} / \mathrm{L}), \mathbf{\square}$ citronellol $(0.3 \mathrm{mg} / \mathrm{L}), \square \alpha$-terpineol $(0.5 \mathrm{mg} / \mathrm{L})$. The data represent the averages of colony diameter of three independent experiments with standard deviations.

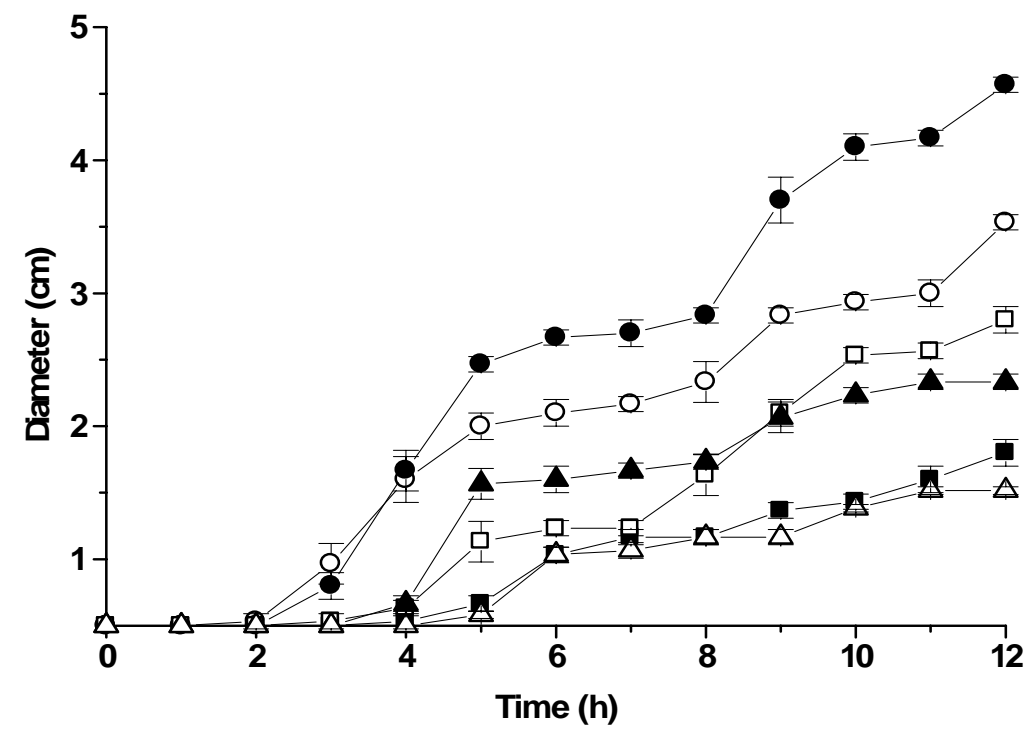

As shown in Figure 4, swarming of $P$. mirabilis was inhibited in a dose dependent manner by the five terpenoids. Complete inhibition was observed in plates containing 0.25 and $0.75 \mathrm{mg} / \mathrm{L}$ of geraniol, and $0.75 \mathrm{mg} / \mathrm{L}$ of citral and citronellol. Similar dose dependent inhibition of swarming behavior on wild-type strains of $P$. mirabilis was previously verified for $p$-nitrophenylglycerol [14], fatty acids [16], and resveratrol [17].

Figure 4. Histogram showing the swarming migration of $P$. mirabilis in the presence of different concentrations of glycerol and selected monoterpenes. Data represent the average of three independent experiments: $\square$ Control; $\otimes 0.06 \mathrm{mg} / \mathrm{L} ; \square 0.12 \mathrm{mg} / \mathrm{L} ; \mathbf{N} 0.25 \mathrm{mg} / \mathrm{L}$; $0.50 \mathrm{mg} / \mathrm{L}$ and $\square 0.75 \mathrm{mg} / \mathrm{L}$.

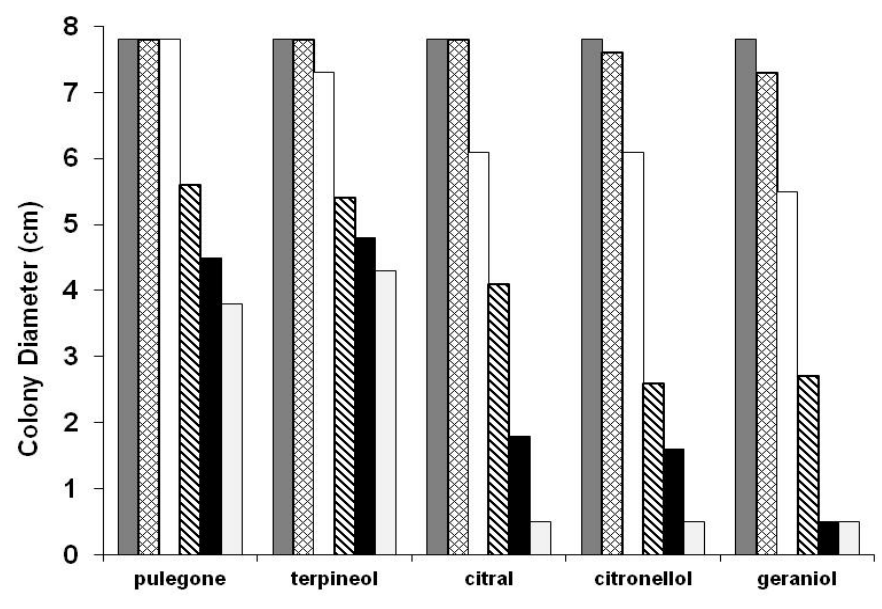


To test if the inhibitory effect of terpenoids on swarming arise from a toxic effect on the bacteria, we evaluated whether 1/10 MIC concentration of selected terpenoids affected the growth rate of $P$. mirabilis L68. P. mirabilis L68 growth was not significantly reduced by citral, citronellol and geraniol, and regardless the presence of the terpenoids, the bacteria reach stationary phase with similar cell density after $16 \mathrm{~h}$ (approx. $10^{9}$ cells $/ \mathrm{mL}$ ), indicating that terpenoids effect on swarming is unlikely to be due to cell growth inhibition.

The swimming/swarming behavior of $P$. mirabilis involves the coordinate differentiation of short, motile, vegetative cells with few peritrichous flagella into long, multi-flagellated, swarm cells [5]. Cell differentiation was evaluated in the presence or absence of terpenoids on LB swarming agar. As can be observed in Figure 5, in the absence of terpenoids, P. mirabilis differentiated into long cell after $4 \mathrm{~h}$, undergoing a rapid reduction on cell length after this period.

Figure 5. Effect of selected monoterpenes on the cell length of $P$. mirabilis L68. The concentration of monoterpenes added were $0.3 \mathrm{mg} / \mathrm{L}$ for citronellol and geraniol, and 0.5 $\mathrm{mg} / \mathrm{L}$ for citral, pulegone and $\alpha$-terpineol. Data represent the average of three independent experiments.

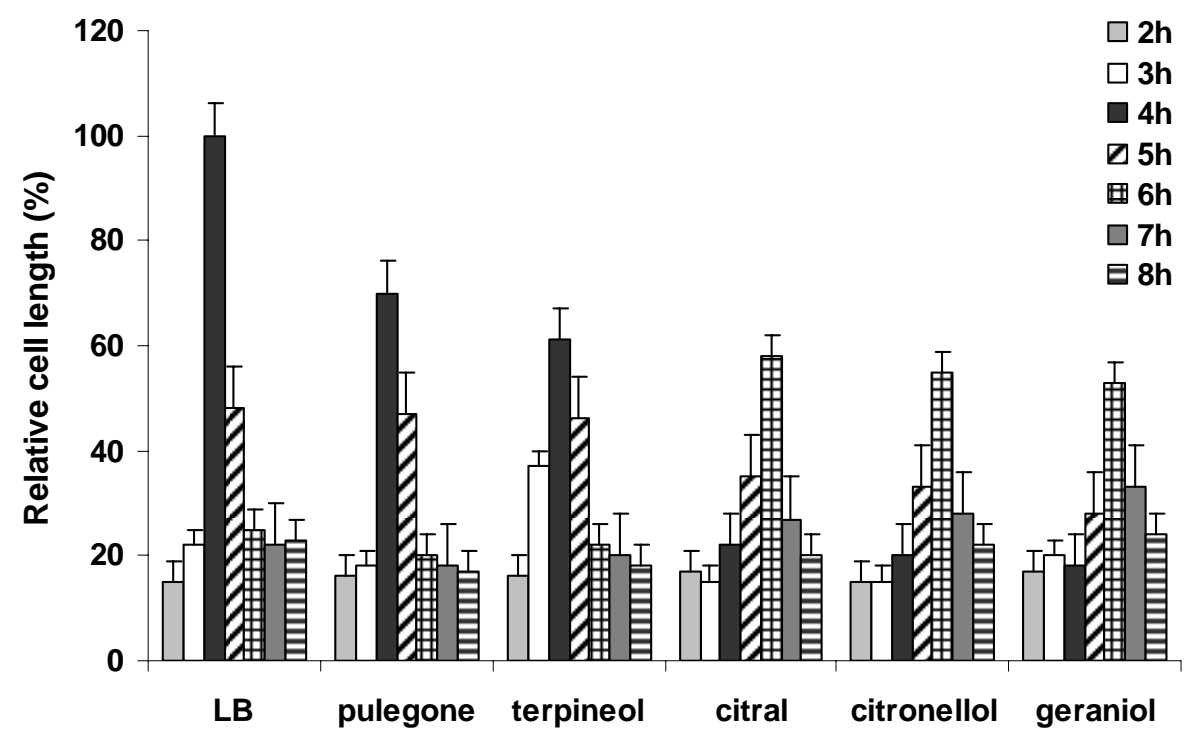

Similar behavior was observed in the presence of $\alpha$-terpineol and pulegone, but elongated cell were detected only $2 \mathrm{~h}$ later in media supplemented with citral, citronellol or geraniol. Moreover, although the five selected terpenoids reduced swarming cell length, cells were particularly shorter in the presence of citral, citronellol and geraniol. These data indicate that terpenoids inhibited swarming by interference in swimming/swarming cell differentiation.

Expression of haemolysin, protease, and urease activities in P. mirabilis, are regulated coordinately with swarming differentiation $[14,15]$. Typical swimming and swarming cells from the cell length experiments (Figure 4) were collected and evaluated for cell membrane-associated haemolysin activity, an important virulence factor in P. mirabilis [9]. As shown in Figure 6, P. mirabilis swarming cells expressed highest haemolysin activities. However, in the presence of monoterpenes, this activity was lower than that of the control. The reduction in haemolysin activity was directly correlated with the reduction in swarming cell length $\left(\mathrm{R}^{2}=0.72\right)$, indicating that terpenoids affect cell differentiation, 
and consequently, haemolysin activity. This relation was observed for other compounds, as nitrophenylglycerol [14], fatty acids [16], and resveratrol [17].

Figure 6. Effect of selected monoterpenes on the haemolysin activity of P. mirabilis L68. The concentration of monoterpenes added were $0.3 \mathrm{mg} / \mathrm{L}$ for citronellol and geraniol, and $0.5 \mathrm{mg} / \mathrm{L}$ for citral, pulegone and $\alpha$-terpineol. Data represent the average of three independent experiments. Vegetative cells (white bars), Swarming cells (gray bars).

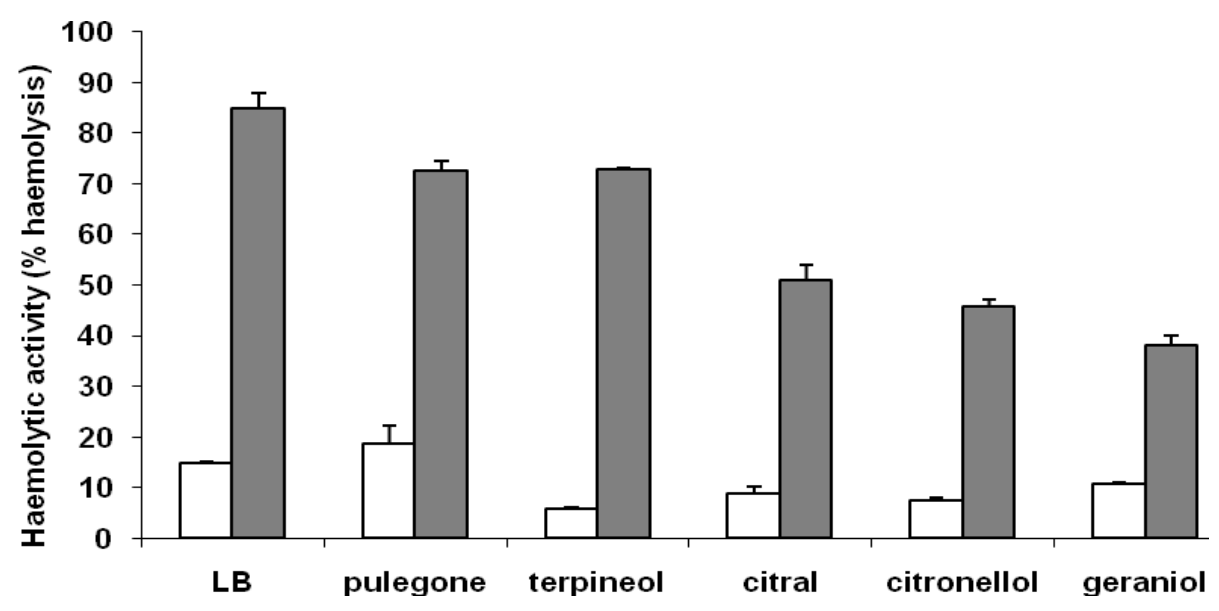

Terpenes and their oxygenated products are relatively inexpensive, stable, abundant, and natural products with high concentration of these compounds, essential oils, are considered as Generally Recognized As Safe (GRAS) [18]. The inhibition of swarming and virulence factor expression suggests that essential oils with high concentration these compounds have the potential to be developed as products for preventing P. mirabilis infections.

\section{Experimental}

Bacterial strain and growth conditions

The bacterial strain used in this study was the wild-type Proteus mirabilis L68, isolated from a patient with chronic urinary tract infection [27]. Bacteria were routinely cultured at $37^{\circ} \mathrm{C}$ in LuriaBertani (LB) medium.

\section{Terpenes and terpenoids}

The seventeen monoterpenes (Table 1) used were purchased from Acros Organics, New Jersey, USA. The purity of these commercial compounds is $>90 \%$.

\section{MIC assay}

The Minimal Inhibitory Concentration assay of terpenes was performed by the broth microdilution [28]. Briefly, serial dilutions of monoterpenes, previously diluted in dimethylsulfoxide (DMSO), were prepared in sterile LB medium in 96-well microtiter plates. Freshly grown bacterial suspensions in LB 
were standardized to $10^{8} \mathrm{CFU} / \mathrm{ml}$, and added to the wells $(10 \mu \mathrm{L})$. The last row containing only the serial dilution of essential oils without bacteria was used as negative control. After incubation at $37^{\circ} \mathrm{C}$ for $24 \mathrm{~h}$ the first well without turbidity was determined as the minimum inhibitory concentration (MIC). Controls without and with DMSO at the same concentration used to dilute the terpenes were included.

\section{Swarming behavior assay}

The swarming migration distance assay was performed as described by Liaw et al. $[15,16]$. Briefly, an overnight $P$. mirabilis L68 culture $(5 \mu \mathrm{L})$ was inoculated centrally onto the surface of dried LB swarming agar (1.5\%) plates without or with different monoterpenes. The plates were incubated at $37^{\circ} \mathrm{C}$, and the swarming migration distance was assayed by measuring the swarm fronts of the bacterial cells and recording progress at 60 min intervals. Controls plates without and with DMSO at the same concentration used to dilute the terpenes were included.

\section{Measurement of cell length}

Measurement of cell length was performed as described by Liaw et al. [16], with modifications. Briefly, stationary-phase LB cultures $(200 \mu \mathrm{L})$ were spread onto LB agar plates without and with appropriate terpenes $\left(1 / 10 \mathrm{MIC}\right.$ concentration) and incubated at $37^{\circ} \mathrm{C}$. Cell from the entire surface of agar plates were harvested with saline $(2 \mathrm{~mL})$ at $1 \mathrm{~h}$ intervals. Bacterial cells were fixed and stained with $0.18 \%$ safranin solution (Merck, Germany), examined by light microscopy (Bioval, China) at a magnification of $1000 \mathrm{x}$, and digitalized using a Samsung digital camera. The lengths of 100 cells in each sample were determined, and the average was calculated. Control plates without and with DMSO at the same concentration used to dilute the terpenes were included.

\section{Membrane-associated haemolysin}

Swimming and swarming cells collected from agar plates were washed with saline and adjusted to a $\mathrm{DO}_{600}=0.7$. Cell membrane-associated haemolysin activity was assayed as previously described by Koronakis et al. [29] and Liaw et al. [16]. Briefly, bacterial suspension (50 $\mu \mathrm{L})$ was mixed with a $2 \%$ erythrocyte suspension $(450 \mu \mathrm{L})$ in $0.85 \% \mathrm{NaCl}$ plus $20 \mathrm{mM} \mathrm{CaCl}_{2}$ and incubated at $40^{\circ} \mathrm{C}$ for $15 \mathrm{~min}$. Haemolytic activity was measured by the release of haemoglobin $\left(\mathrm{A}_{543}\right)$ using a $100 \%$ positive haemolysin-positive reference.

\section{Acknowledgements}

This work was supported by grants from the CNPq, CAPES, and FAPERGS.

\section{References}

1. Mobley, H.L.; Belas, R. Swarming and pathogenicity of Proteus mirabilis in the urinary tract. Trends Microbiol. 1995, 3, 280-284.

2. Senior, B.W. Proteus morgani is less frequently associated with urinary tract infections than Proteus mirabilis- an explanation. J. Med. Microbiol. 1983, 35, 203-207. 
3. Fraser, G.M.; Hughes, C. Swarming motility. Curr. Opin. Microbiol. 1999, 2, 630-635.

4. Sturgill, G.; Rather, P.N. Evidence that putrescine acts as an extracellular signal required for swarming in Proteus mirabilis. Mol. Microbiol. 2004, 51, 437-446.

5. Rather, P.N. Swarmer cell differentiation in Proteus mirabilis. Environ. Microbiol. 2005, 7, 1065 1073.

6. Wassif, C.; Cheek, D.; Belas, R. Molecular analysis of a metalloprotease from Proteus mirabilis. J. Bacteriol. 1995, 177, 5790-5798.

7. Rozalski, A.; Sidorczyk, Z.; Katelko, K. Potential virulence factors of Proteus bacilli. Microbiol. Mol. Biol. Rev. 1997, 61, 65-89.

8. Fraser, G.M.; Claret, L.; Furness, R.; Gupa, S.; Hughes, C. Swarming-coupled expression of the Proteus mirabilis hpmBA haemolysin operon. Microbiology 2002, 148, 2191-2201.

9. Mobley, H.L.; Belas, R.; Lockatell, V.; Chippendale, G.; Trifillis, A.L.; Johnson, D.E.; Warren, J.W. Construction of a flagellum negative mutant of Proteus mirabilis: effect on internalization by human renal epithelial cells and virulence in a mouse model of ascending urinary tract infection. Infect. Immunity 1996, 64, 5332-5340.

10. Walker, K.E.; Moghaddame-Jafari, S.; Locktell, C.V.; Johnson, D.; Belas, R. ZapA, the IgAdegradin metalloprotease of Proteus mirabilis, is a virulence factor expressed specifically in swarmer cells. Mol. Microbiol. 1999, 32, 825-836.

11. Alwen, J.; Smith, D.G. A medium to suppress the swarming of Proteus species. J. Appl. Microbiol. 1967, 30, 389-394.

12. William, F.D. Abolition of swarming of Proteus by p-nitrophenyl glycerin: general properties. Appl. Environ. Microbiol. 1973, 25, 745-750.

13. Hernandez, E.; Ramisse, F.; Carvalho, J.D. Abolition of swarming of Proteus. J. Clin. Microbiol. 1999, 37, 3435.

14. Liaw, S.J.; Lai, H.C.; Ho, S.W.; Luh, K.T.; Wang, W.B. Inhibition of virulence factor expression ad swarming differentiation in Proteus mirabilis by p-nitrophenylglycerol. J. Med. Microbiol. 2000, 49, 725-731.

15. Liaw, S.J.; Lai, H.C.; Ho, S.W.; Luh, K.T.; Wang, W.B. Characterization of pnitrophenylglycerol-resistant Proteus mirabilis super-swarming mutants. J. Med. Microbiol. 2001, 50, 1039-1048.

16. Liaw, S.J.; Lai, H.C.; Wang, W.B. Modulation of swarming and virulence by fatty acids through the RsbA protein in Proteus mirabilis. Infect. Immunity 2004, 72, 6836-6845.

17. Wang, W.B; Lai, H.C.; Hsueh, P.R.; Chiou, R.Y.; Lin, S.B.; Liaw, S.J. Inhibition of swarming and virulence factor expression in Proteus mirabilis by resveratrol. J. Med. Microbiol. 2006, 55, 1313-1321.

18. Cowan, M.M. Plant products as antimicrobial agents. Clin. Microbiol. Rev. 1999, 12, 564-582.

19. Trombetta, D.; Castelli, F.; Sarpietro, M.G.; Venuti, V.; Cristani, M.; Daniele, C.; Saija, A.; Mazzanti, G.; Bisignano, G. Mechanisms of antibacterial action of three monoterpenes. Antimicrob. Agents Chemother. 2005, 49, 2474-2478.

20. Hammer, K.A.; Carson, C.F.; Riley, T.V. Antimicrobial activity of essential oils and other plant extracts. J. Appl. Microbiol. 1999, 86, 985-990. 
21. Essawi, T.; Srour, M. Screening of some Palestinian medicinal plants for antibacterial activity. $J$. Ethnopharmacol. 2000, 70, 343-349.

22. Burt, S.A. Essential oils: their antibacterial properties and potential applications in foods: a review. Int. J. Food Microbiol. 2004, 94, 223-253.

23. Kotan, R.; Kordali, S.; Cakir, A. Screening of antibacterial activities of twenty-one oxygenated monoterpenes. Z. Naturforsch. C 2007, 62, 507-513.

24. Mansouri, S.; Amari, A.; Asad, A.G. Inhibitory effect of some medicinal plants from Iran on swarming motility of Proteus rods. J. Med. Sci. 2005, 5, 216-221.

25. Naigre, R.; Kalck, P.; Roques, C.; Rocux, I.; Michel, G. Comparison of antimicrobial properties of monoterpenes and their carbonylated products. Planta Med. 1996, 62, 275-277.

26. Dahr, P.; Ayala, U.; Andarge, E.; Morisseau, S.; Snyder-Leiby, T. Study of the structural changes on the antimicrobial activity of [3.1.1.]-bicyclics. J. Essent. Oil Res. 2004, 16, 612-616.

27. Costa, S.O.P.; Bianco, M.; Bonato M.C. Instability of protease (gelatinase) trait in Proteus mirabilis. Rev. Microbiol. 1982, 13, 35-45.

28. Mann, C.M.; Markham, J.L. A new method for determining the minimum inhibitory concentration of essential oils. J. Appl. Microbiol. 1998, 84, 538-544.

29. Koronakis, V., Cross, M.; Senior, B.; Koronakis, E.; Hugues, C. The secreted hemolysins of Proteus mirabilis, Proteus vulgaris, and Morganella morganii are genetically related to each other and to the alpha-hemolysin of Escherichia coli. J. Bacteriol. 1987, 169, 1509-1515.

Sample Availability: Requests for samples of the terpenes should be directed to Dr. Sergio Echeverrigaray.

(C) 2008 by the authors; licensee Molecular Diversity Preservation International, Basel, Switzerland. This article is an open-access article distributed under the terms and conditions of the Creative Commons Attribution license (http://creativecommons.org/licenses/by/3.0/). 